\title{
PENGUATAN PROMOSI PRODUK UMKM MELALUI PENGGUNAAN BAHASA YANG KOMUNIKATIF: STUDI KASUS UMKM OLLY COOKIES DAN RENDANG YUGO
}

\author{
Ridwan Hanafiah ${ }^{1)}$ \\ ${ }^{1)}$ Fakultas Ilmu Budaya, Universitas Sumatera Utara \\ E-mail: ridwances@yahoo.com
}

\begin{abstract}
Abstrak
Jumlah UMKM di Indonesia yang cukup banyak berpotensi untuk meningkatkan perekonomian negara, namun dalam pengembangannya para pengusaha sering kali dihadapkan pada berbagai macam hambatan. Secara umum ada 2 permasalahan utama, yaitu finansial dan non finansial. Salah satu masalah non financial adalah kurangnya promosi. Penggunaan bahasa yang komunikatif dapat menjadi salah satu solusi dalam menguatkan pemasaran produk UMKM. Studi ini diharapkan dapat merubah pandangan masyarakat pesisir dalam memasarkan produknya dengan menggunakan bahasa yang komunikatif guna meningkatkan hasil penjualan mereka khususnya masyarakat pesisir di desa nelayan Belawan. Metode pelaksanaan pengabdian masyarakat pemberdayaan Masyarakat pesisir dirancang secara komprehensif dan proporsional melalui In-class discussion dengan tujuan untuk menumbuhkan kepekaan (awareness) dan membangun kerangka berfikir (framework of thinking) terhadap Mitra dan pelaku UMKM untuk memanfaatkan kekuatan bahasa dalam melakukan promosi bagi produk mereka.
\end{abstract}

Kata Kunci: pemasaran, bahasa, UMKM

\section{PENDAhuluan}

Usaha Mikro Kecil Menengah dan Koperasi (UMKM) sebagai sektor ekonomi nasional yang sangat strategis dalam pembangunan ekonomi kerakyatan, selalu menjadi isu sentral yang diperebutkan oleh politisi dalam menarik simpati massa. Para akademisi dan LSM juga banyak mendiskusikannya dalam forum-forum seminar, namun jarang sekali yang melakukan upaya riil sehingga berdampak pada peningkatan kesejahteraan UMKM.Sebagai poros kebangkitan perekonomian nasional, UMKM tenyata bukan sektor usaha yang tanpa masalah.Dalam perkembangannya, sektor ini justru menghadapi banyak masalah yang sampai saat ini belum mendapat perhatian serius untuk mengatasinya. Ali (2008) menyatakan bahwa UMKM merupakan benteng pertahanan ekonomi nasional sehingga bila sektor tersebut diabaikan sama artinya tidak menjaga benteng pertahanan Indonesia.

Sejarah telah menunjukkan bahwa Usaha Kecil dan Mikro (UMKM) di Indonesia tetap eksis dan berkembang dengan adanya krisis ekonomi yang telah melanda negeri ini sejak tahun 1997, bahkan menjadi katup penyelamat bagi pemulihan ekonomi bangsa karena kemampuannya memberikan sumbangan yang cukup signifikan pada PDB maupun penyerapan tenaga kerja. Dari 224.000 unit usaha mikro, kecil, dan menengah yang beroperasi di Medan, sebanyak 7.800 unit bergerak di bidang industri kreatif, seperti periklanan, arsitektur, seni, kerajinan, desain, fashion, film, musik, seni pertunjukkan, dan penerbitan. 
Kepala Dinas Koperasi dan UKM Medan Qamarul Fattah (dikutip dalam Harian Bisnis Indonesia) mengatakan pihaknya berupaya mendorong pembentukan usaha industri kreatif, sehingga peran kreatifitas sumber daya manusia terhadap perekonomian Medan semakin besar. Qamarul mengemukakan salah satu upaya yang dilakukan pemerintah kota mengembangkan industri kreatif di Medan adalah dengan memediasi pelaku usaha dengan pemilik modal, baik melalui perbankan, maupun lembaga lain. Lebih jauh, dia mengemukakan UMKM di Kota Medan sebagian besar dalam bentuk salon, usaha pengangkutan, dan ekspedisi yang mencapai angka 198.000 pelaku usaha. Sementara itu, untuk usaha perdagangan, seperti pedagang makanan kecil, warung hingga kios mencapai angka17.000 pelakuusaha.

Pemasaran merupakan unsur yang cukup vital dari sebuah keberlangsungan usaha bisnis. Hampir 90\% kesuksesan sebuah bisnis sangat dipengaruhi oleh upaya marketing atau pemasaran. Oleh karena itu dibutuhkan manajemen pemasaran yang baik, kreatif, dan berkualitas. Sehingga produk yang kita pasarkan dapat diterima oleh masyarakat luas (http://fahrull1412.blogspot.co.id/2016/10/ peranan-bahasa-dalam-manajemenpemasaran.html. diakses pada 4 Mei 2018). Salah satu teknik pemasaran adalah dalam bentuk iklan.

Rachmadi (1993:37) berargumen bahwa iklan atau promosi adalah komunikasi persuasif yang mengajak calon pembeli untuk menerima citra sebagaimana yang ditayangkan. Hal ini diperkuat dengan pendapat Práca dan Lapšanská (2006) bahwa "advertising is a means of promotion the product, idea, or organization on the market with the aim to give information and to persuade people of the advantage of the product and induce them to take and action". Pendapat diatas juga sejalan dengan Suyatno (2004: 56) yang menyatakan bahwa periklanan memiliki beberapa fungsi yaitu pemberi informasi, persuasi, pengingat, penambah nilai, dan pendamping produk. Kata kunci yang dapat kita simpulkan adalah bahasa. Semakin komunikatif bahasa yang digunakan maka pesan yang disampaikan dalam iklan tersebut akan tersampaikan dan dimengerti dengan baik sehingga pelanggan akan membeli produk atau membayar jasa mereka. Oleh sebab itu, urgensi penggunaan bahasa yang komunikatif menjadi hal yang mutlak dipertimbangkan.

Dilihat dari fenomena kultural dan sosial, fungsi bahasa sebagai sarana komunikasi manusia, maka bahasa dapat dikaji berdasarkan teori bahasa, baik secara internal, eksternal, dan interdisplin (Hanafiah, 2016). Selanjutnya, bahasa, bagaimana pun juga, merupakan salah satu komponen-komponen komunikasi yang tentu saja tidak bisa dilepaskan begitu saja. Tanpa adanya bahasa, komunikasi mungkin tidak bisa terjadi dengan begitu baik (https://pakarkomunikasi.com/fungsi-

bahasa-dalam-komunikasi-bisnis. diakses pada 4 Mei 2018). Selanjutnya, Agustin, Hilaliyah, \& Yunus (2015) juga menyatakan bahwa pengaruh bahasa iklan terhadap masyarakat sangatlah besar. Masyarakat banyak menggunakan jargon yang dikembangkan dari media massa; seperti "Gojek-in aja", "buka aja bukalapak", "bukan basa-basi", "apapun makanannya, minumnya ....". Hal ini menunjukkan bahwa bahasa iklan mudah melekat dalam ingatan masyarakat. Jika pelanggan tidak ingat dengan produk sesuatu, bagaimana mereka akan membeli produk tersebut? Bahasa yang komunikatif dalam iklan pada dasarnya dapat memberi pengaruh terhadap perilaku berbahasa secara praktis pada masyarakat. Bahkan, bahasa iklan dapat membentuk kebiasaan berbahasa masyarakat (Agustin, Hilaliyah, \& Yunus, 2015).

Pengabdian ini bertujuan untuk memberdayakan Usaha Mikro Kecil dan Menengah (UMKM) yang bergerak dalam bidang usaha makanan olahan dalam menggunakan bahasa yang komunikatif dalam pemasaran produk masyarakat pesisir 
Ridwan. Penguatan Promosi Produk UMKM Melalui Penggunaan Bahasa yang Komunikatif : Studi Kasus UMKM Olly Cookies dan Rendang Yugo

desa nelayan Belawan. Mitra dalam pengabdian ini adalah usaha Rendang Yugo dan Olly Cookies.

\section{PENGERTIAN BAHASA}

Bahasa merupakan alat komunikasi yang dimiliki oleh dan menjadi ciri khas manusia yang menggunakannya. Pada umumnya manusia selalu menggunakan bahasa dalam beraktivitas antarsesamanya dalam kehidupan sehari-hari, yang dalam ilmu linguistik manusia disebut pula homo longuens (Hanafiah, 2016). Walau begitu besarnya arti bahasa dalam kehidupan manusia, tetapi kita selalu melupakan untuk memikirkan peranan bahasa. Koentjaraningrat (1967) mengatakan bahwa bahasa merupakan unsur vital dalam kebudayaan. Suatu kebudayaan yang tinggi derajatnya didukung oleh suatu bahasa dengan kesusastraan yang tinggi, walaupun suatu bahasa pada dasarnya hanya berfungsi sebagai alat komunikasi praktis antarsesama penuturnya. Levi-Strauss (1963) juga mengatakan bahwa bahasa dan kebudayaan merupakan hasil dari aktivitas manusia. Hubungan bahasa dan kebudayaan ini dapat menjelaskan berbagai fenomena dan sistem kekerabatan sebagai rangkaian hubungan simbolis.

\section{FUNGSI BAHASA}

Dilihat dari fungsi bahasa sebagai sarana komunikasi manusia, maka bahasa dapat dikaji berdasarkan teori bahasa, baik secara internal, eksternal, dan interdisplin. Kajian internal merujuk pada struktur internal bahasa dalam arti linguistik, sedangkan kajian eksternal merupakan kajian yang melibatkan faktor-faktor yang berada di luar bahasa yang melibatkan lebih dari disiplin ilmu bahasa saja tetapi ke bidang ilmu lain yaitu sosiolinguistik, antropolinguistik, akustik, psikolinguistik, ekonomi dan lainlain (Hanafiah, 2016).

Wijaya (2006) dalam Hanafiah (2016) menyimpulkan pendapat berbagai ahli ke dalam tiga hubungan antara bahasa dengan struktur masyarakat penuturnya. Ketiganya adalah: (i) hubungan struktur bahasa mempengaruhi masyarakat di mana struktur bahasa menentukan cara-cara yang dipakai penutur bahasa dalam melaksanakan kegiatan sehari-hari; (ii) hubungan masyarakat mempengaruhi bahasa di mana budaya masyarakat tampak dalam struktur bahasa yang digunakannya; dan, (iii) hubungan itu dapat ada tetapi dapat tidak ada sama sekali, antara bahasa dan budaya.

\section{JENIS-JENIS BAHASA DALAM IKLAN}

Bahasa periklanan, tentu saja, biasanya sangat positif dan menekankan mengapa satu produk menonjol dibandingkan dengan yang lain. Bahasa iklan tidak selalu menjadi bahasa yang "benar" dalam arti normal. Sebagai contoh, perbandingan sering digunakan ketika tidak ada perbandingan nyata yang dibuat. Iklan untuk deterjen mungkin mengatakan "Itu mendapat pakaian lebih putih", tetapi lebih putih dari apa?

Kannan \& Tyagi (2013) menjelaskan beberapa jenis bahasa yang digunakan dalam iklan yaitu:

1. Hiperbola

2. Neologisme

3. Frasa kata benda yang panjang

4. Kalimat Pendek

5. Ambiguitas

6. Weasel words

7. Eufimisme

8. Bahasa sehari-hari

9. Bahasa yang familiar

10. Kosa kata yang simple

\section{PENGGUNAAN BAHASA YANG KOMUNIKATIF DAN KESUKESAN IKLAN}

Bahasa memiliki pengaruh kuat atas orang dan perilaku mereka. Ini terutama berlaku di bidang pemasaran dan periklanan. Pilihan bahasa untuk menyampaikan pesan tertentu dengan maksud mempengaruhi orang sangat penting. Konten dan desain visual dalam iklan memiliki dampak yang sangat besar pada konsumen, tetapi bahasalah yang 
membantu orang untuk mengidentifikasi suatu produk dan mengingatnya (Kannan \& Tyagi, 2013).

Suatu produk akan melekat dibenak fikiran orang jika bahasa yang digunakan dalam iklan memiliki karakteristik tertentu. Jefkins (1997) dalam Agustin, Hilaliyah, \& Yunus (2015) mengungkapkan bahwa teks iklan yang memiliki karakteristik, orisinal, dan persuasif dapat tercipta jika memenuhi syarat-syarat sebagai berikut. a) Teks iklan yang ditulis harus bersifat menjual, meskipun iklan hanya bertujuan untuk mengingatkan saja, b) Rahasia keberhasilan iklan adalah pengulangan (repetition), apakah pengulangan itu dengan memanfaatkan iklan secara kontinyu ataudengan menerapkan pengulangan dalam tubuh teks iklan itu sendiri, c) Orang tidak akan peduli untuk membaca teks iklan karena pesan iklan harus memanfaatkan secara maksimal kata-kata dan menyampaikan pesannya dengan segera, $d$ ) Jika pembaca merasa tidak familiar terhadap suatu kata yang asing, perhatian pembaca terhadap iklan tersebut akan hilang. Oleh karena itu, setiap kata yang digunakan harus mudah dipahami dan tidak ada kemungkinan untuk menimbulkan keraguan di benak pembaca, dan e) Kata-kata singkat, kalimat-kalimat pendek, paragraf yang tidak terlalu panjang membantu menyampaikan pesan iklan serta memudahkan pembaca untuk memahami dan mengerti maksud teks iklan itu dengan cepat.

Uturodewo (2003:381) mengatakan bahwa hal yang perlu ditandai dalam laras iklan adalah bahwa kita tidak perlu selalu menggunakan kalimat lengkap. Ketidaklengkapan kalimat dalam teks iklan ini merupakan usaha pembuat iklan untuk menarik perhatian dan menciptakan teks yang singkat dan berisi. Bahasa iklan harus menggunakan bahasa yang komuikatif dan tetap memperhatikan kaidah tatabahasa yang ada (Agustin, Hilaliyah, \& Yunus, 2015).
Leech (1972:25) menulis, bahwa bahasa periklanan yang disebut sebagai "loaded language". Leech mengatakan bahwa bahasa yang dimuat memiliki tujuan untuk mengubah kemauan, pendapat, atau sikap audiensnya. Dia mengklaim bahwa iklan berbeda dari jenis bahasa lain yang dimuat (seperti jurnalisme politik dan pidato keagamaan) dalam memiliki tujuan material yang sangat tepat - mengubah disposisi mental untuk mencapai jenis perilaku yang diinginkan - membeli jenis produk tertentu.

\section{HASIL}

Jumlah UMKM di Indonesia yang cukup banyak berpotensi untuk meningkatkan perekonomian negara, namun dalam pengembangannya para pengusaha sering kali dihadapkan pada berbagai macam hambatan.Secara umum ada 2 permasalahan utama, yaitu finansial dan non finansial.Masalah finansial umumnya berkaitan dengan hambatan UMKM dalam memenuhi kebutuhan pembiayaan untuk mengembangkan usahanya.Masalah pembiayaan merupakan hambatan yang paling sering dikeluhkan oleh para pengusaha, baik usaha kecil maupun besar (Wismiarsi dkk, 2008:18). Dalam pertemuan tingkat Menteri APEC bidang UKM di Amerika, Menteri Koperasi dan UKM Syarief Hasan menegaskan bahwa permasalahan akses pembiayaan merupakan hambatan utama bagi setiap usaha yang ingin mengembangkan produksinya (Rakyat Merdeka, 26 Mei 2011).

Kegiatan pengabdian Masyarakat dilaksanakan di 2 Mitra yaitu Bapak Azwir dan Bapak Sugito.Kedua Mitra berada di satu Desa yaitu Desa Nelayan Lingkungan 8 Kelurahan Nelayan Indah Kecamatan Medan Belawan.Tim Pengabdi sesuai kepakaran memberikan kontribusi dalam kegiatan ini. Kegiatan Program Pengabdian Masyarakat ini menggandeng 2 mitra yaitu:

- Mitra 1 :Lisa Lolita. Alamat:Jl. Garu 3 Komp. Sempurna Indah No. A4 Medan 
- Mitra 2 :Merry Fersy. Alamat :Jl. Menteng Gg. Pembangunan Ujung Medan

Pada tanggal 11 Mei 2018, tim pengabdian menyiapkan alat dan bahan dalam pelatihan, menyiapkan tempat untuk pelatihan, dan Menyiapkan peserta dalam penyuluhan penggunaan bahasa yang komunikatif dalam promosi produk olahan makanan mitra. Mitra dan masyarakat sekitar secara aktif telah berkontribusi dalam pelatihan/penyuluhan yang telah dilaksanakan.

\section{KESIMPULAN}

Sebagai bentuk komunikasi persuasif yang mengajak calon pembeli untuk menerima citra sebagaimana yang ditayangkan, iklan haruslah menarik dari segi bahasa. Bahasa yang komunikatif merupakan salah satu faktor yang memainkan peranan penting dalam kesuksesan sebuah promosi produk. Walau secara struktur kalimat terkadang tidak lengkap atau sempurna, hal tersebut merupakan usaha pembuat iklan untuk menarik perhatian dan menciptakan teks yang singkat dan berisi. Kegiatan Pengabdian Masyarakat ini telah dilakukan dengan baik, Tim pelaksana telah memberikan penyuluhan dan pelatihan sesuai dengan keahlian masing-masing. Mitra juga sudah memahami dan mulai menggunakan bahasa yang komunikatif dalam promosi produk mereka.

\section{SARAN}

Berdasarkan hasil pengabdian ini disarankan kepada pemerintah untuk ikut aktif membina dengan memberikan pelatihan-pelatihan kepada para pelaku UMKM untuk melakukan promosi produk mereka. Karena selama ini pelatihan yang dilakukan hanya untuk meningkatkan kualitas produk UMKM saja, tidak kepada cara melakukan promosi yang baik. Sehingga produk yang mereka telah hasilkan tidak dapat diketahui oleh masyarakat.Sehingga usaha para UMKM tidak dapat berkembang seperti yang mereka inginkan.

\section{UCAPAN TERIMA KASIH}

Kegiatan pengabdian masyarakat yang telah dilaksanakan telah dapat diselesaikan dengan dan didapat hasil yang diharapkan dapat diadopsi oleh masyarakat. Dalam pelaksanaan kegiatan ini, tim peneliti banyak mendapat bantuan dari bebagai kalangan, sehingga kegiatan pengabdian ini dapat terlaksana. Sehubungan dengan hal tersebut, tim peneliti mengucapkan terima kasih kepada LPPM USU yang telah membiayai kegiatan ini.

\section{DAFTAS PUSTAKA}

Agustin,Y., Hilaliyah, H., \& Yunus, S. (2015). Penggunaan Bahasa Iklan pada Papan Reklame (Studi Survei Sepanjang Kampung Rambutan sampai dengan Lebak Bulus). Jurnal Pujangga. 1(2), 54-65.

Hanafiah, R. (2016). Bahasa dan Politik: Realitas pada Parlok Aceh. Medan: Bartong Jaya.

Jefkins, F. (1997). Periklanan. Jakarta: Erlangga.

Kannan, R. dan Tyagi, S. (2013). Use of Language in Advertisements. English for Specific Purposes World, 37(1), 1-10.

Práca, D. dan Lapšanská, J. (2006). The Language of Advertising with the Concentration on the Linguistic Means and the Analysis of Advertising Slogans. Diploma thesis. Bratislava: Univerzita Komenského.

Rachmadi, F. (1993). Public Relation dalam Teori dan Praktik. Jakarta: Gramedia Pustaka Utama.

Suyatno, M. (2004). Aplikasi Desain Grafis untuk Periklanan. Yogyakarta: Andi Offset. 
Ridwan. Penguatan Promosi Produk UMKM Melalui Penggunaan Bahasa yang Komunikatif : Studi Kasus UMKM Olly Cookies dan Rendang Yugo

Uturodewo, F.N. (2003). Iklan sebagai Media Pembinaan Bahasa Indonesia. Depok: Universitas Indonesia.

http://fahrull1412.blogspot.co.id/2016/10/pera nan-bahasa-dalam-manajemenpemasaran.html. diakses pada 4 Mei 2018.

https://pakarkomunikasi.com/fungsi-bahasadalam-komunikasi-bisnis. diakses pada 4 Mei 2018. 